\title{
Acetylcholinesterase, Specific Acetylcholinesterase and Total Protein Concentrations in the Brain Regions of Broiler Chickens Fed Dietary Monosodium Glutamate
}

\author{
Olumuyiwa Joseph Olarotimi1 ${ }^{1, a, *}$, Imoleayo Sarah Oladeji1 ${ }^{1, b}$, Olufemi Adesanya ADU1,c, Francis Ayodeji Gbore ${ }^{2, d}$ \\ ${ }^{I}$ Department of Animal Production and Health, School of Agriculture and Agricultural Technology, The Federal University of Technology, \\ Akure, P.M.B. 704, Ondo state, Nigeria \\ ${ }^{2}$ Department of Animal Science, Adekunle Ajasin University, Akungba-Akoko, Nigeria \\ *Corresponding author
}

\begin{tabular}{|c|c|}
\hline A R T I C L E I N O & A B S T R A C T \\
\hline $\begin{array}{l}\text { Keywords: } \\
\text { Broilers } \\
\text { Brain } \\
\text { MSG } \\
\text { Diets } \\
\text { Protein }\end{array}$ & $\begin{array}{l}\text { The study was carried out to examine the effect of varied levels of dietary monosodium glutamate } \\
\text { on acetylcholinesterase, specific acetylcholinesterase and total protein concentrations in the brain } \\
\text { regions of broiler chickens. Three hundred (300) day - old unsexed Abor - acre chickens were } \\
\text { randomly assigned to diets: A, B, C, D, E and F containing } 0.00,0.25,0.50,0.75,1.00 \text { and } 1.25 \mathrm{~g} / \mathrm{kg} \\
\text { MSG respectively. Each treatment was replicated } 5 \text { times with } 10 \text { birds per replicate. The birds were } \\
\text { fed ad - libitum and provided with clean water for } 8 \text { weeks (56 days) after which } 2 \text { birds per } \\
\text { replicates were slaughtered. The brains were removed, dissected into different regions comprising } \\
\text { of the olfactory lobe, pineal body, optic lobe, cerebellum and the medulla oblongata. The different } \\
\text { parts of the brain were homogenized to determine the acetylcholinesterase and total protein which } \\
\text { were also used in the assessment of the specific acetylcholinesterase of the brain. No significant } \\
\text { differences were observed in the acetylcholinesterase activity of the olfactory lobe, pineal body, } \\
\text { optic lobe, cerebellum except for the medulla. Likewise, the dietary monosodium glutamate did not } \\
\text { influence the activities of the total protein and specific acetylcholinesterase of the olfactory lobe } \\
\text { portion of the brain. The dietary monosodium glutamate exerted significant effects on the total } \\
\text { protein of other brain parts studied and which invariably resulted in significant changes in the } \\
\text { specific acetylcholinesterase of the optic lobe, cerebellum and medulla except for the optic lobe. } \\
\text { This study revealed that monosodium glutamate added to broilers diet above } 0.75 \mathrm{~g} / \mathrm{kg} \text { significantly } \\
\text { altered the concentration of the brain acetylcholinesterase, total protein and specific } \\
\text { acetylcholinesterase thereby impaired brain functions. }\end{array}$ \\
\hline
\end{tabular}

olarotimioj@futa.edu.ng (iD) https://orcid.org/0000-0002-5934-2529

oaadu@futa.edu.ng (iD) https://orcid.org/0000-0001-8967-7752

b@olaimoleayo@gmail.com

fgbore@gmail.com

(iD) https://orcid.org/0000-0003-3587-4907

(i) https://orcid.org/0000-0002-2634-3330

(c) (1) (8) This work is licensed under Creative Commons Attribution 4.0 International License

\section{Introduction}

There has been growing concerns in recent years on the use of monosodium glutamate in the food industry due to its perceived negative implication on the health of the consumers. Monosodium glutamate (MSG) is a food additive consumed in most part of the world as flavor enhancer (Farombi and Oyema, 2006). It is a precursor of non-essential amino acids such as arginine, glutamine and proline (Blachieret al., 2009). It is present in most animal products such as meat, egg, milk and milk products as either bound or free glutamate with a greater proportion of it being in the bound form (Yamaguchi and Ninomiya, 1998). The glutamate present in MSG act as neurotransmitter in the brain, modifies the breakdown of amino acids, protein production and proteolysis when consumed regularly (Paddon et al., 2004; Nakashima et al.,
2005) but causes neurotoxic effects when consumed in large amount (Fernandez and Hernnandez, 2005). Likewise, higher dosage of MSG administration had adverse effect on the cerebellum of adult wistar albino rats which resulted into tremor, ataxia and uncontrollable movement of the rats (Eweka and Om'Iniabohs, 2007). Despite numerous negative consequences of high dose of MSG on laboratory animals and humans, international bodies and organizations such as the Food and Drug Administration (FDA) as well as National Agency for Food and Drug Administration Control (NAFDAC) in Nigeria considered MSG as a safe flavor enhancing additive (Walker and Lupien, 2000). Since the market share of broiler chicken meat has increased in recent years and several reports has reviewed the potency of MSG in 
improving the feed intake and weight gain of birds, utilizing it in the poultry industry will be great gain. The avian brain controls all body functions and as a result is easily affected by the age, feed, enzymes and hormones secreted in the body of an animal (Adejumo and Egbunike, 2004). Thus, the dearth of knowledge on the implication of dietary MSG on the brain parts of broiler chicken triggered the investigation of effect of varied levels of dietary MSG on the acetylcholinesterase (AChE) activities, total protein and specific acetylcholinesterase (SAChE) of the brain of broiler chickens in this present study.

\section{Materials and Methods}

The experiment was conducted using three hundred (300) day-old unsexed and Arbor -acre broiler chicks. This study lasted for eight weeks at the Poultry unit of the livestock section of Teaching and Research Farm, The Federal University of Technology, Akure. The chicks were weighed on arrival and randomly assigned to six treatments (diets) containing 0, 0.25, 0.50, 0.75, 1.00 and 1.25 MSG. Each treatment was replicated five times with 10 birds per replicate in a completely randomized design. Broiler starter and finishers diet was fed to the birds at $0-4$ weeks and 4 8 weeks as shown in Table 1 and 2 respectively.

At the end of the experiment, two birds per replicate were slaughtered, that is, a sum of 10 birds per treatment and the brains were removed immediately, freed of all adhering meninges and blood vessels. The brains obtained were dissected on ice-cold porcelain tile into the cerebellum, cerebral cortex, mid brain and medulla oblongata as described by Adejumo and Egbunike (2001). The brain hypophyseal acetylcholinesterase (AChE) activities and total protein concentrations were determined by colorimetic method according to Ellmann et al. (1961) and Biuret method of Reinhold (1953) respectively using Randox commercial kits with catalog numbers TP245 and CE7944 for TP and AChE respectively. Thereafter, the brain and hypophyseal samples from each animal was homogenized (1\% weight per volume (w/v) with a PotterElvehjem homogenizer with catalog number P7734 in $0.1 \mathrm{M}$ (ice-cold phosphate buffer containing $0.1 \%$ Triton $\mathrm{X}$ 100. The AChE activity of each sample was divided by its total protein concentration to give the specific acetylcholinesterase (SAChE) activity in $\mu \mathrm{mole} / \mathrm{g}$ protein/min.

All data collected were subjected to One Way Analysis of Variance (ANOVA) at $\alpha=0.05$ using SAS (2008, version 9.2). Duncan Multiple Range Test of the same software was used for means comparison where significant differences existed as outlined by Snedecor and Cochran (1980).

\section{Results}

It was observed that the different inclusion levels of MSG did not have a significant influence on the olfactory lobe, pineal body, optic lobe and cerebellum acetylcholinesterase concentration of the brain as shown in Table 3. However, a significant $(\mathrm{P}<0.05)$ effect was observed on the medulla oblongata acetylcholinesterase activity of the brain. There was no significant difference in the activity of the medulla acetylcholinesterase among the birds fed diets containing $0.00-1.00 \mathrm{~g} / \mathrm{kg}$ MSG but a significant $(\mathrm{P}<0.05)$ decrease in the activity of acetylcholinesterase was observed among the birds on the diet containing $1.25 \mathrm{~g} / \mathrm{kg}$ MSG when compared with those on the control diet and the diet containing $0.50 \mathrm{~g} \mathrm{MSG} / \mathrm{kg}$.

Table 1 Ingredient composition of the experimental starter diets

\begin{tabular}{|c|c|c|c|c|c|c|}
\hline \multirow{2}{*}{ Ingredients (kg) } & \multicolumn{6}{|c|}{ Inclusion Level of MSG $(\mathrm{g} / \mathrm{kg})$} \\
\hline & $\mathrm{A}$ & B & $\mathrm{C}$ & $\mathrm{D}$ & $\mathrm{E}$ & $\mathrm{F}$ \\
\hline Maize & 510 & 509.75 & 509.5 & 509.25 & 509 & 508.75 \\
\hline Soyabean Meal & 150 & 150 & 150 & 150 & 150 & 150 \\
\hline Groundnut cake & 150 & 150 & 150 & 150 & 150 & 150 \\
\hline Fish Meal & 50 & 50 & 50 & 50 & 50 & 50 \\
\hline Corn bran & 106 & 106 & 106 & 106 & 106 & 106 \\
\hline Bone Meal & 15 & 15 & 15 & 15 & 15 & 15 \\
\hline Limestone & 10 & 10 & 10 & 10 & 10 & 10 \\
\hline Salt & 3.5 & 3.5 & 3.5 & 3.5 & 3.5 & 3.5 \\
\hline MSG & 0 & 0.25 & 0.5 & 0.75 & 1 & 1.25 \\
\hline Lysine & 1 & 1 & 1 & 1 & 1 & 1 \\
\hline Methionine & 2 & 2 & 2 & 2 & 2 & 2 \\
\hline Broiler Premix ${ }^{*}$ & 2.5 & 2.5 & 2.5 & 2.5 & 2.5 & 2.5 \\
\hline Total & 1000 & 1000 & 1000 & 1000 & 1000 & 1000 \\
\hline \multicolumn{7}{|c|}{ Calculated Nutrients } \\
\hline $\mathrm{ME}(\mathrm{Kcal} / \mathrm{Kg})$ & 2985.82 & 2977.24 & 2968.66 & 2960.08 & 2951.5 & 2925.76 \\
\hline Crude Protein $(\%)$ & 22.6 & 22.58 & 22.56 & 22.24 & 22.22 & 22.15 \\
\hline Calcium $(\%)$ & 1.28 & 1.28 & 1.28 & 1.28 & 1.28 & 1.28 \\
\hline Phosphorus (\%) & 0.52 & 0.52 & 0.52 & 0.51 & 0.51 & 0.51 \\
\hline Lysine & 1.15 & 1.15 & 1.15 & 1.15 & 1.15 & 1.15 \\
\hline Methionine & 0.56 & 0.56 & 0.56 & 0.56 & 0.56 & 0.56 \\
\hline Crude Fibre (\%) & 3.68 & 3.68 & 3.67 & 3.66 & 3.66 & 3.65 \\
\hline
\end{tabular}

${ }^{*}$ Composition of Broiler Premix (Nutrivitas $\left.{ }^{\circledR)}\right): 2.5 \mathrm{~kg}$ of premix contains: Vit. A $(10,000,000 \mathrm{iu})$, Vit. D3 (2,500,000 iu), Vit. E (12,000 iu), Vit. B1 (2000 mg), Niacin (25000 mg), Vit. B6 (1500 mg), Vit. B12 (10 mg), Vit. K3 (2500 mg), Biotin (75 mg), Folic Acid (2000 mg), Panthothenic Acid (7000 mg), Chlorine Chloride (50\%) (200000 mg), Manganese (80000 mg), Iron (40000 mg), Copper (10,000 mg), Zinc (60000 mg), Selenium (200 $\mathrm{mg}$ ), Iodine (1500 mg), Magnesium (100 mg), Ethoxyquine (500 g), BHT (700 g), Cobalt (250 mg). MSG = monosodium glutamate. 
Table 2 Ingredient composition of the experimental finisher diets

\begin{tabular}{|c|c|c|c|c|c|c|}
\hline \multirow{2}{*}{ Ingredients $(\mathrm{kg})$} & \multicolumn{6}{|c|}{ Inclusion Level of MSG (g/kg) } \\
\hline & $\mathrm{A}$ & $\mathrm{B}$ & $\mathrm{C}$ & $\mathrm{D}$ & $E$ & $\mathrm{~F}$ \\
\hline Maize & 500 & 499.75 & 499.5 & 499.25 & 499 & 498.75 \\
\hline Soybean meal & 130 & 130 & 130 & 130 & 130 & 130 \\
\hline Groundnut cake & 130 & 130 & 130 & 130 & 130 & 130 \\
\hline Rice Bran & 133 & 133 & 133 & 133 & 133 & 133 \\
\hline Corn Bran & 60 & 60 & 60 & 60 & 60 & 60 \\
\hline Bone Meal & 25 & 25 & 25 & 25 & 25 & 25 \\
\hline Limestone & 10 & 10 & 10 & 10 & 10 & 10 \\
\hline Salt & 3.5 & 3.5 & 3.5 & 3.5 & 3.5 & 3.5 \\
\hline MSG & 0 & 0.25 & 0.50 & 0.75 & 1.00 & 1.25 \\
\hline Lysine & 3 & 3 & 3 & 3 & 3 & 3 \\
\hline Methionine & 3 & 3 & 3 & 3 & 3 & 3 \\
\hline Broiler Premix ${ }^{*}$ & 2.5 & 2.5 & 2.5 & 2.5 & 2.5 & 2.5 \\
\hline Total & 1000 & 1000 & 1000 & 1000 & 1000 & 1000 \\
\hline \multicolumn{7}{|c|}{ Calculated Nutrients } \\
\hline ME (Kcal/Kg) & 2964.16 & 2955.58 & 2947 & 2938.2 & 2929.84 & 2921.26 \\
\hline Crude Protein $(\%)$ & 18.56 & 18.54 & 18.52 & 18.5 & 18.48 & 18.46 \\
\hline Calcium (\%) & 1.24 & 1.24 & 1.23 & 1.23 & 1.23 & 1.23 \\
\hline Phosphorus (\%) & 0.56 & 0.56 & 0.56 & 0.55 & 0.55 & 0.55 \\
\hline Lysine & 1.08 & 1.08 & 1.08 & 1.08 & 1.08 & 1.08 \\
\hline Methionine & 0.57 & 0.57 & 0.57 & 0.57 & 0.57 & 0.57 \\
\hline Crude Fibre $(\%)$ & 4.85 & 4.83 & 4.83 & 4.82 & 4.82 & 4.81 \\
\hline
\end{tabular}

${ }^{*}$ Composition of Broiler Premix (Nutrivitas $\left.{ }^{\circledR)}\right): 2.5 \mathrm{~kg}$ of premix contains: Vit. A (10,000,000 iu), Vit. D3 (2,500,000 iu), Vit. E (12,000 iu), Vit. B1 (2000 mg), Niacin (25000 mg), Vit. B6 (1500 mg), Vit. B12 (10 mg), Vit. K3 (2500 mg), Biotin (75 mg), Folic Acid (2000 mg), Panthothenic Acid (7000 mg), Chlorine Chloride (50\%) (200000 mg), Manganese (80000 mg), Iron (40000 mg), Copper (10,000 mg), Zinc (60000 mg), Selenium (200 $\mathrm{mg}$ ), Iodine (1500 mg), Magnesium (100 mg), Ethoxyquine (500 g), BHT (700 g), Cobalt (250 mg). MSG = monosodium glutamate.

Table 3 Brain Acetylcholinesterase (AChE) Activities of Broilers Fed Different Levels of MSG

\begin{tabular}{l|ccccccc}
\multicolumn{1}{c}{ Parameters } & $\mathrm{A}(0.00)$ & $\mathrm{B}(0.25)$ & $\mathrm{C}(0.50)$ & $\mathrm{D}(0.75)$ & $\mathrm{E}(1.00)$ & $\mathrm{F}(1.25)$ & $\mathrm{P}-$ Value \\
\hline Olfactory lobe & $0.16 \pm 0.01$ & $0.13 \pm 0.04$ & $0.13 \pm 0.02$ & $0.16 \pm 0.01$ & $0.13 \pm 0.02$ & $0.17 \pm 0.01$ & $0.6369^{\mathrm{ns}}$ \\
Pineal body & $0.16 \pm 0.00$ & $0.16 \pm 0.01$ & $0.16 \pm 0.01$ & $0.16 \pm 0.03$ & $0.15 \pm 0.01$ & $0.16 \pm 0.03$ & $0.9960^{\mathrm{ns}}$ \\
Optic lobe & $0.16 \pm 0.01$ & $0.15 \pm 0.01$ & $0.13 \pm 0.02$ & $0.12 \pm 0.01$ & $0.12 \pm 0.00$ & $0.16 \pm 0.01$ & $0.2113^{\mathrm{ns}}$ \\
Cerebellum & $0.15 \pm 0.01$ & $0.13 \pm 0.01$ & $0.11 \pm 0.00$ & $0.15 \pm 0.01$ & $0.13 \pm 0.02$ & $0.11 \pm 0.02$ & $0.3659^{\text {ns }}$ \\
Medulla Oblongata & $0.24 \pm 0.01^{\mathrm{a}}$ & $0.22 \pm 0.06^{\mathrm{ab}}$ & $0.24 \pm 0.05^{\mathrm{a}}$ & $0.18 \pm 0.01^{\mathrm{ab}}$ & $0.13 \pm 0.02^{\mathrm{ab}}$ & $0.11 \pm 0.01^{\mathrm{b}}$ & $0.0494^{*}$ \\
\hline
\end{tabular}

Values are means \pm SEM, Means in a row without a common superscript are significantly $(\mathrm{P}<0.05)$ different, Level of significance $=\mathrm{ns}(\mathrm{not}$ significant $)$ $=\mathrm{P} \geq 0.05 ; *=\mathrm{P} \geq 0.01<0.05$

Table 4 Brain Specific Acetylcholinesterase (SAChE) Activities of Broilers Fed Different Levels of MSG

\begin{tabular}{l|ccccccc}
\hline \multicolumn{1}{c|}{ Parameters } & $\mathrm{A}(0.00)$ & $\mathrm{B}(0.25)$ & $\mathrm{C}(0.50)$ & $\mathrm{D}(0.75)$ & $\mathrm{E}(1.00)$ & $\mathrm{F}(1.25)$ & $\mathrm{P}-$ Value \\
\hline Olfactory lobe & $0.78 \pm 0.09$ & $0.73 \pm 0.06$ & $0.62 \pm 0.01$ & $0.87 \pm 0.30$ & $0.57 \pm 0.13$ & $0.78 \pm 0.02$ & $0.6849^{\mathrm{ns}}$ \\
Pineal body & $0.63 \pm 0.02$ & $0.63 \pm 0.08$ & $0.71 \pm 0.07$ & $0.63 \pm 0.07$ & $0.86 \pm 0.05$ & $0.86 \pm 0.15$ & $0.1741^{\mathrm{ns}}$ \\
Optic lobe & $0.66 \pm 0.00^{\mathrm{c}}$ & $0.71 \pm 0.04^{\mathrm{c}}$ & $0.63 \pm 0.00^{\mathrm{c}}$ & $0.82 \pm 0.03^{\mathrm{b}}$ & $0.88 \pm 0.06^{\mathrm{b}}$ & $0.98 \pm 0.01^{\mathrm{a}}$ & $<0.0001^{* * * *}$ \\
Cerebellum & $0.91 \pm 0.05$ & $0.77 \pm 0.07$ & $0.72 \pm 0.05$ & $0.98 \pm 0.04$ & $1.07 \pm 0.13$ & $0.76 \pm 0.12$ & $0.0698^{\mathrm{ns}}$ \\
Medulla & $1.28 \pm 0.07$ & $1.50 \pm 0.48$ & $1.89 \pm 0.49$ & $0.90 \pm 0.12$ & $0.90 \pm 0.09$ & $0.77 \pm 0.16$ & $0.1274^{\mathrm{ns}}$ \\
\hline
\end{tabular}

Values are means \pm SEM, Means in a row without a common superscript are significantly $(\mathrm{P}<0.05)$ different, Level of significance $=\mathrm{ns}(\mathrm{not}$ significant $)$ $=\mathrm{P} \geq 0.05 ; * * * *=\mathrm{P}<0.0001$

The varied inclusion levels of dietary MSG, as shown in Table 4, did not significantly influence the activities of specific acetylcholinesterase of the olfactory lobe, pineal body, cerebellum and medulla of the brain across all treatment groups. This was not the case for optic lobe as the inclusion level from $0.75 \mathrm{~g} / \mathrm{kg}$ to $1.25 \mathrm{~g} / \mathrm{kg}$ significantly $(\mathrm{P}<0.05)$ increased the activity of specific acetylcholinesterase with those on $1.25 \mathrm{~g} / \mathrm{kg}$ recording the highest value.

Furthermore, the total protein in the pineal body, optic lobe, cerebellum and medulla was significantly influenced $(\mathrm{P}<0.05)$ except for the olfactory lobe of the brain as revealed in table 4 . The total protein of the pineal body increased above the control when MSG was added to the diet of the bird but at $1.25 \mathrm{~g} / \mathrm{kg}$ inclusion level, the effect of the dietary MSG on the total protein of the pineal body was similar to that of the control. The effect of dietary MSG did not follow a regular pattern on the total protein of the optic lobe and broiler chickens fed $0.25 \mathrm{~g} / \mathrm{kg}$ dietary MSG possessed the highest total protein in their optic lobe. Likewise, diets B and D increased the total protein of the cerebellum but no changes were observed in the total protein of the medulla of birds given diet containing 0.75 $\mathrm{g} / \mathrm{kg}$ MSG and above. 
The result of the brain total protein of broiler chickens fed graded levels of MSG is as shown in Table 5. From the result, there was no significant influence on the olfactory lobe of the birds across all the treatments. However, there were significant $(\mathrm{P}<0.05)$ effects of $\mathrm{MSG}$ on the pineal body, optic lobe and cerebellum. Cocks on diets A - D showed statistical similarity while those on diets $\mathrm{E}$ and $\mathrm{F}$ were significantly $(\mathrm{P}<0.05)$ different for the three parameters. For medulla oblongata, cocks on diets A and B showed similarity while those on $\mathrm{C}-\mathrm{F}$ were not significantly different but were significantly $(\mathrm{P}<0.05)$ different when compared with the control.

Table 5 Brain Total Protein of Broilers Fed Different Levels of MSG

\begin{tabular}{l|ccccccc}
\hline \multicolumn{1}{c|}{ Parameters } & $\mathrm{A}(0.00)$ & $\mathrm{B}(0.25)$ & $\mathrm{C}(0.50)$ & $\mathrm{D}(0.75)$ & $\mathrm{E}(1.00)$ & $\mathrm{F}(1.25)$ & $\mathrm{P}-$ Value \\
\hline Olfactory lobe & $0.20 \pm 0.01$ & $0.17 \pm 0.03$ & $0.21 \pm 0.03$ & $0.22 \pm 0.06$ & $0.23 \pm 0.02$ & $0.21 \pm 0.01$ & $0.8263^{\mathrm{ns}}$ \\
Pineal body & $0.25 \pm 0.00^{\mathrm{a}}$ & $0.26 \pm 0.01^{\mathrm{a}}$ & $0.24 \pm 0.03^{\mathrm{a}}$ & $0.25 \pm 0.02^{\mathrm{a}}$ & $0.17 \pm 0.00^{\mathrm{b}}$ & $0.18 \pm 0.00^{\mathrm{b}}$ & $0.0077^{* *}$ \\
Optic lobe & $0.23 \pm 0.01^{\mathrm{a}}$ & $0.21 \pm 0.00^{\mathrm{ab}}$ & $0.21 \pm 0.03^{\mathrm{ab}}$ & $0.16 \pm 0.01^{\mathrm{ab}}$ & $0.14 \pm 0.01^{\mathrm{c}}$ & $0.14 \pm 0.02^{\mathrm{c}}$ & $0.0172^{*}$ \\
Cerebellum & $0.17 \pm 0.00^{\mathrm{ab}}$ & $0.17 \pm 0.00^{\mathrm{a}}$ & $0.15 \pm 0.01^{\mathrm{ab}}$ & $0.15 \pm 0.01^{\mathrm{ab}}$ & $0.12 \pm 0.01^{\mathrm{c}}$ & $0.14 \pm 0.01^{\mathrm{b}}$ & $0.0030^{* *}$ \\
Medulla Oblongata & $0.19 \pm 0.01^{\mathrm{a}}$ & $0.20 \pm 0.01^{\mathrm{a}}$ & $0.13 \pm 0.01^{\mathrm{b}}$ & $0.15 \pm 0.01^{\mathrm{b}}$ & $0.14 \pm 0.01^{\mathrm{b}}$ & $0.15 \pm 0.02^{\mathrm{b}}$ & $0.0025^{* *}$ \\
\hline
\end{tabular}

Values are means \pm SEM, Means in a row without a common superscript are significantly $(\mathrm{P}<0.05)$ different, Level of significance $=\mathrm{ns}(\mathrm{not}$ significant $)$ $=\mathrm{P} \geq 0.05 ; *=\mathrm{P} \geq 0.01<0.05 ; * *=\mathrm{P} \geq 0.001<0.01$

\section{Discussions}

Brain AChE and SAChE Activities of the MSG-Treated Broilers

The non-significant difference observed in the acetylcholinesterase activities of olfactory lobe, pineal body, optic lobe and cerebellum regions of the brain of the treated birds signified that MSG inclusion at the experimental dosage used in this study did not have influence on the broiler chickens. However, a significant effect was only observed in the acetylcholinesterase activity of the medulla oblongata region of the brain among the birds on diet $1.25 \mathrm{~g} / \mathrm{kg} \mathrm{MSG}$. The dose-dependent nonsignificant effect observed in this study might be as a result of short duration of exposure to the MSG-treated feed. The present result contradicted many earlier reports which documented either increase or decrease in the AChE activity of the treated animals. Abu-Taweel (2016) reported a decrease in the AChE activity in MSG treated rats while Lucinei et al. (2000), Khedr (2016) and Fasakin et al. (2017) reported an increase the activities of AChE in MSG treated mice. The result of this study showed there was no dysfunction in the cholinergic system of the birds, and hence, resulted in consistence of the enzyme. It is, therefore, speculative in this study that the non-significant difference observed in the AChE activity in the brain region of the birds may lead to consistent cholinergic neurotransmission efficiency. Furthermore, the AChE activity in the medulla oblongata that was not significantly different indicated that normal synthesis and catabolism of neurotransmitters (AChE) were presumably only affected when the birds were fed MSG above a tolerable level of $1.25 \mathrm{~g} / \mathrm{kg}$ diet. For the pineal gland, the insignificant effect noted in the AChE of the birds across the treatment diets in comparison with the control showed that dietary MSG at the inclusion levels did not tamper with melatonin production thereby did not affect negatively the modulation of sleeping pattern and behavior of the bird. The insignificant effect of the dietary MSG on activity of the AChE of the olfactory lobes of the birds revealed that their sense of smell was not negatively affected by the treatment diets which is attributed to the fact that birds have the least sense of smell and do not use smell extensively to make most of their decisions (Maynitz, 2018). The significant elevations observed in the SAChE activities of the optic lobe among the cocks on the diet containing 0.75 MSG and above in this study agreed with the reports of
Bond (2017) who stated that excessive quantity of MSG induced an alteration in the functions of the SAChE activity of the brain as neurotransmitter. Adejumo and Egbunike (2004) concurred with the non-significant influence observed in the SAChE activities of the cerebellum, medulla oblongata, olfactory lobe and pineal gland regions of the brain. $M S G$

Brain Total Protein of Broilers Fed Different Levels of

The significantly lower concentration of total protein in the pineal gland, cerebellum, optic lobe and medulla oblongata of birds on diets containing above $0.75 \mathrm{~g} / \mathrm{kg}$ MSG and $0.25 \mathrm{~g} / \mathrm{kg}$ for medulla oblongata is indicative of the interference of dietary MSG with neural mechanisms involved with protein synthesis. The insignificant decrease in the total protein concentration in the olfactory lobe of the birds confirms the possibility of the interference of MSG with protein synthesis in some brain sections. Ewuola and Bolarinwa (2017) explained that the ability of aflatoxin to bind and interfere with enzymes and substrates that are needed in the initiation, transcription and translation process involved in protein synthesis makes it capable of affecting the brain development. If there significant difference in the total protein of the olfactory lobe, this would have led to retina dysfunction. Ohguro et al. (2002) had reported a scenario in rats fed 10 grams MSG/100 gram daily diet which had led to a significant increase in amount of glutamic acid in vitreous and consequently had damaged to the retina.

\section{Conclusion}

This study revealed that monosodium glutamate could offset neurotransmission in broiler chickens at an inclusion level above $0.75 \mathrm{~g} / \mathrm{kg}$ due to its excitotoxin nature. Hence, there is likelihood of homeostatic imbalance in the birds fed high level of dietary monosodium glutamate. Further investigation will be a novelty since the brain is the control box for all animals.

\section{References}

Abu-Taweel GM. 2016. Effect of monosodium glutamate and aspartame on behavioral and biochemical parameters of male albino mice. Afri. J. Biotech. 15(15): 601-612. 
Adejumo DO, Egbunike GN. 2001. Effect of prepubertal, pubertal and postpubertalorchidectomy and testosterone therapy on theacetylcholinesterase activity and protein content in brain and hypophyses of Pigs.Trop. Anim. Prod. \& Inv. J., 4:157-165.

Adejumo DO, Egbunike GN. 2004. Changes in acetylcholinesterase activities in the developing and aging pig brain and hypophyses. Int'l. J. Agric. Rural Dev., 5:46 -53.

Blachier F, Boutry C, Bos C, Tomé D. 2009. Metabolism and functions of L-glutamate in the epithelial cells of the small and large intestines. Ame. J. Clin. Nutri., 1:814-821.

Bond O. 2017. Neurological effect of monosodium glutamate. www.livestrong.com. Accessed 3rd October, 2018.

Ellman GL, Courtney KD, AndresVJ, Featherstone RM. 1961. A new and rapid calorimetric determination of acetylcholinesterase activity. Biochem. Pharm., 7: 88 -95.

Eweka AO. 2007. Histological studies of the effects of monosodium glutamate on the cerebellum of adult Wistar rats. J. Neuro., Neurosurg. \& Psychiat., 8: 2-7.

Eweka AO, Om'Iniabohs FAE. 2011. Histological studies of the effects of monosodium glutamate on the ovaries of adult wistar rats. Ann. Med. Health Sci. Res., 1: 37-43.

Ewuola EO, Bolarinwa OA. 2017. Acetylcholinesterase, glucose and total protein concentration in the brain regions of West African dwarf goat fed dietary aflatoxin. J. Vet. Med. \& Anim. Health, 19: $240-245$.

Farombi EO, Onyema OO. 2006. Monosodium glutamateinduced oxidative damageandgenotoxicity in the rat: modulatory role of vitamin $\mathrm{C}$, vitamin $\mathrm{E}$ and guercetin. Human Exper. Toxicol., 125:251-259.

Fernandez T, Hernnandez JA. 2005. Effect of monosodium glutamate given orally onappetite control (a new theory for the obesity epidemic). Anal. de la Real Acad. Nacionalde Med., 122 :341.
Khedr NF. 2016. Curcumin protects against monosodium glutamate neurotoxicity and decreasing NMDA2B and mGluR5 expression in rat hippocampus. Neurosignals. 24: 81-87

Lucinei BS, Gravena C, Bonfleur ML, de Freitas MPC. 2000. Insulin secretion and acetylcholinesterase activity in monosodium L-glutamate-induced obese mice. Hor. Res. Pediatr. 54(4): 1186-1191.

Maynitz M. 2018. Bird senses - sight, hearing, touch, taste and smell. How birds use their sense. The spruce. https://www.thespruce.com/birds-five-senses-386441. Accessed January 30, 2018

Nakashima K, Ishida A, Yamazaki M, Abe H. 2005. Leucine suppresses myofibrillar proteolysis by down - regulating ubiquitin- proteasome pathway in chick skeletal muscles. Biochem. \& Biophy. Res. Comm., 336: 660 - 666.

Ohguro H, Katsushima H, Maruyama I. 2002. A high dietary intake of sodium glutamate as flavoring (Ajinomoto) causes gross changes in retinal morphology and function. Exp Eye Res. 75 (3): 307-15.

Paddon JD, Sheffield MM, Zhang XJ, Volpi E, Wolf SE. 2004. Amino acid ingestion improves muscle protein synthesis in the young and elderly. Ame. J. Physiol., Endocrinol. \& Metabol., 286: 321 -328.

Snedecor GW, Cochran WG. 1980. Statistical methods. Book, PP. $4207^{\text {th }}$ ED. Lowa Stat. Univ. Press, Ames, Lowa, U.S.A.

Walker R, Lupien JR. 2000. The safety of monosodium glutamate. Journal of Nutrtion 130 (4):1049-1052

Yamaguchi S, Ninomiya K. 1998. What is unami?.Food Rev. Int'1., 14: 123 - 138 . 